\title{
FAKTA POLIGAMI SEBAGAI BENTUK KEKERASAN TERHADAP PEREMPUAN
}

\author{
Siti Hikmah, S.Pd., M.Si ${ }^{1}$ \\ Fakultas Dakwah IAIN Walisongo Semarang
}

\begin{abstract}
Abstrak
Poligami merupakan suatu jalan yang diambil perempuan karena keterpaksaan. Poligami menjadi suatu dilema, diterima ataupun tidak tetap memiliki konsekuensi terjadinya kekerasan terhadap perempuan. Istri pertama maupun kedua, sama sama terjerat dan tertindas dalam sistem kemasyarakatan yang dikuasai oleh sistem masyarakat patriarkhi. Berangkat dari analisa tersebut, maka segala argumen yang menyatakan bahwa poligami telah menyelamatkan perempuan tidak benar sama sekali.

Praktek perkawinan poligami lebih berdampak kemadharatan daripada kemaslahatan. Dalam perkawinan poligami banyak terjadi pengabaian hak-hak kemanusiaan yang semestinya didapatkan oleh seorang istri dan anak dalam keluarga. Hal ini yang kemudian sering muncul adalah adanya permusuhan diantara keluarga para istri dalam perkawinan poligami. Realitasnya banyak kasus poligami yang memicu bentuk-bentuk kekerasan dalam rumah tangga (KDRT) lainnya, meliputi kekerasan fisik, psikis, seksual dan ekonomi dan sebagainya yang dialami oleh perempuan dan anak-anak menjadi bukti bahwa semestinya ada peninjauan dan pertimbangan kembali tentang adanya praktek perkawinan poligami.
\end{abstract}

Kata Kunci: poligami, fakta, kekerasan, perempuan

\section{A. Pendahuluan}

Berbicara tentang poligami, kita akan teringat adanya fenomena pernikahan kedua $\mathrm{A}^{\prime} \mathrm{a} \mathrm{Gym}^{2}$ yang mengundang kontroversi berbagai kalang-

\footnotetext{
${ }^{1}$ Pendiri Women Crisis Center (WCC) Jombang.
} 
an. Banyak kalangan yang angkat bicara seputar pernikahan tersebut, mulai dari masyarakat biasa, pemuka agama, aktivis perempuan, artis bahkan pejabat negara. Sebagian mengatasnamakan dalil agama untuk melegitimasi dibolehkannya poligami, namun sebagian lainnya tidak setuju karena merasa dirugikan. Begitu besarnya reaksi masyarakat tentang hal ini sampai-sampai pada saat itu Presiden SBY menghimbau rakyatnya untuk menanggapi permasalahan ini secara proporsional dan tidak berlebihan. Hal ini menunjukkan pada kita bahwa isu poligami bukan lagi wacana seputar konteks keagamaan, namun telah menjadi isu sosial yang meresahkan masyarakat.

Poligami adalah masalah yang serius dan karena itu wajar saja bila banyak kaum perempuan yang meributkannya. Karena kita tahu bahwa separuh lebih penduduk Indonesia (51\% data BPS 2000) adalah perempuan. Oleh sebab itu kepentingan perempuan mayoritas ini menjadi kepentingan yang patut didengarkan.

Suara menentang poligami telah secara lantang disuarakan perempuan sejak tahun 1911 dimulai dengan Kartini, seorang pahlawan nasional. Tahun 1928 Kongres Perempuan pertama menuntut larangan poligami, tahun 1930 Kelompok Federasi Asosiasi Perempuan Indonesia menyerukan hal yang sama, dan sampai sekarang masih terus diperjuangkan karena poligami berdampak pada kekerasan terhadap perempuan dan anak, sehingga poligami tidak dapat ditolerir karena lebih banyak merugikan kaum perempuan.

Tulisan ini bermaksud menggambarkan bagaimana budaya patriarkhi dapat mendukung suburnya poligami, bagaimana ketidakadilan yang

2 Pernikahan kedua KH. Abdullah Gimnastiar (yang biasa disebut A'a Gym) dengan mantan model yang biasa disebut dengan Teh Rini mendapat kecaman publik, pernikahan kedua tersebut berdampak pada jadwal ceramah yang menurun tajam sampai pada bisnis A'a Gym yang dikabarkan mengalami kebangkrutan. Dua tahun setelah pernikahan kedua, A'a Gym menceraikan istri pertamanya yang telah memberi tujuh anak. Tujuh bulan setelah bercerai dengan istri pertama, A'a Gym menikah yang ketiga kali dengan mantan istri pertamanya (yang biasa dipanggil teh ninih) pada bulan maret 2012. 
dijelaskan dalam al-Qur'an sama dengan kekerasan terhadap perempuan, serta bagaimana poligami dalam sejumlah fakta dapat menjelaskan korelasinya pada kekerasan terhadap perempuan dan anak.

\section{B. Akar Poligami}

Poligami dalam Kamus Besar Bahasa Indonesia adalah istilah untuk menyebut tindakan seorang laki-laki yang menikah dengan perempuan lebih dari satu dalam waktu yang sama. Sebagai sistem perkawinan sendiri poligami lebih dikenal dengan istilah "poligini" perilaku ini telah ada berabad-abad. Kisah-kisah kehidupan nabi dalam kitab suci Taurat pun telah menggambarkan perilaku poligami sebagai kebiasaan yang diterima masyarakat pada saat itu. Menurut Hasan Halthout ${ }^{3}$, Nabi Sulaiman a.s. mempunyai 700 orang istri yang merdeka dan 300 orang istri berasal dari budak.

Perkembangan wacana feminisme dan analisa gender kemudian melahirkan cara pandang baru terhadap tata hubungan laki-laki dan perempuan. Analisa gender memberikan pemahaman bahwa laki-laki dan perempuan itu sama, yang membedakan ialah jenis kelaminnya. Sedang perbedaan perilaku antara laki-laki dan perempuan dikonstruksi melalui proses sosial dan kultural yang panjang dan dapat berubah-ubah.

Perbedaan ini pada akhirnya memunculkan banyak ketidakadilan misalnya marjinalisasi, stereotype, subordinasi, kekerasan, beban kerja ganda pada perempuan. Para feminis kemudian mempertanyakan mengapa dan bagaimana perbedaan gender dapat melahirkan ketidakadilan pada perempuan? menurut feminis radikal Kate Millet mengatakan bahwa ketidakadilan tersebut disebabkan oleh adanya relasi kuasa laki-laki yang dominan terhadap perempuan. Hubungan laki-laki dan perempuan dalam masyarakat adalah hubungan politik yaitu hubungan yang didasarkan pada struktur kekuasaan, suatu sistem masyarakat dimana satu kelompok manusia dikendalikan oleh kelompok manusia yang lainnya. Nama struktur kekuasaan dimana laki-laki mengendalikan perempuan adalah

\footnotetext{
${ }^{3}$ Lihat Hathout, Hasan, Revolusi Seksual Perempuan, (Bandung: Mizan, 1995), h. 51.
} 
patriarkhi, sedangkan lembaga utama dari sistem patriarkhi adalah keluarga. ${ }^{4}$

Menurut kaum feminis radikal dan eksistensialis, keluarga adalah sumber dari penindasan dan ajang objektifikasi perempuan. Mary Wollstoecraft menjuluki perkawinan sebagai prostitusi yang dilegalkan karena semata-mata digunakan untuk mengontrol dan melindungi perempuan dari ancaman seksualitas laki-laki. Namun faktanya justru kekerasan domestik tumbuh subur dalam perkawinan. ${ }^{5}$

Hingga kini masih sulit ditemukan suatu batasan yang ketat untuk mendefinikan poligami sebagai salah satu bentuk kekerasan terhadap perempuan tetapi beberapa definisi dapat digunakan untuk mengenali poligami sebagai salah satu kekerasan terhadap perempuan. Toety Nurhadi mendefinisikan kekerasan sebagai suatu tindakan pemaksaan baik secara persuasif maupun fisik ataupun gabungan keduanya. Pemaksaan juga berarti pelecehan terhadap kehendak pihak lain, yang mengalami pelecehan hak-haknya secara total, eksisitensinya sebagai manusia dengan akal, rasa, kehendak dan integritas tubuhnya tidak dikehendaki lagi. Sedangkan poligami dalam kasus kekerasan menurut Coomaraswany yang dikutip oleh Tamrin A. Tamagola dikategorikan sebagai kekerasan berdasarkan motif yang berbentuk kejahatan yang berdalih kehormatan. Kekerasan jenis ini muncul sebagai akibat pemposisian perempuan sebagai pihak yang menjadi tanggungan dan mendapat perlindungan dari seorang laki-laki, ayahnya dan kemudian suaminya. ${ }^{6}$

Penempatan perempuan sebagai pihak yang menjadi tanggungan merupakan akibat dari stereotype ideology patriarkhi terhadap perempuan. Ideologi ini menempatkan label pada perempuan, tidak saja pada aspek psiko-

${ }^{4}$ Mansour Fakih, Analisis Gender dan Transformasi Sosial, (Yogyakarta: Pustaka Pelajar, 1996) h. 71, 106. lihat juga, Arief Budiman, Pembagian Kerja Secara Seksual: Sebuah Pembahasan Sosiologis tentang Peran Wanita di dalam Masyarakat, (Jakarta: Gramedia, 1981), h. 10-14.

${ }^{5}$ Lengkapnya baca Mary Woolstonecrfaft, The Vindications of The Rights of Women (London: Penguin Books, 1992), baca juga Rosemarie Putnam Tong, Feminist Thought, a Mor Comprehensive Introduction, (Colorado: Westview, 1998), h. 179-189.

${ }^{6}$ Beberapa pengkategorian kekerasan terhadap perempuan dapat dilihat pada tulisan A. Tamalgola, dalam "Negara dan Kekerasan terhadap Perempuan", Jurnal Perempuan, (Jakarta: Yayasan Jurnal Perempuan, 2000) h. 38. 
logis tetapi juga aspek teknis. Perempuan dianggap sebagai makhluk yang lemah, lembut dan cengeng. Pelabelan ini membuat perempuan dipandang tidak mampu memimpin. Pemimpin membutuhkan karakter kuat, tegas dan rasional serta memiliki kemampuan teknis yang handal. Inilah yang dimutlakkan sebagai karakter laki-laki.

Dalam konteks keluarga, perempuan ditetapkan sebagai pihak yang dipimpin, sedangkan laki-laki adalah pemimpin. Akibatnya, perempuan tidak memiliki hak untuk memutuskan sesuatu dalam keluarga. Disinilah gejalah kekerasan terhadap perempuan pada kasus poligami tampak. Meski demikian, berbagai kalangan yang pro poligami, membantah pengkategorian poligami sebagai praktik kekerasan terhadap perempuan. Mereka mengatakan poligami merupakan suatu bentuk perlindungan terhadap perempuan karena jumlah perempuan lebih banyak dari pada laki-laki, sehingga poligami membantu laki-laki dan perempuan untuk dapat menikmati seks dan memperoleh keturunan. Disamping itu poligami mencegah laki-laki dari penyelewengan dan tindak kekerasan akibat frustasi tidak memperoleh pemenuhan kebutuhan seksual, poligami sekaligus melindungi perempuan karena mereka dapat "berbagi tugas" dalam memuaskan kebutuhan seksual laki-laki. Argumentasi diatas sebenarnya hanya membuat stereotype ideology patriarkhy terhadap perempuan semakin nyata.

Argumentasi tersebut sangat berlawanan dengan realitas yang ada. Misalnya argumentasi tentang jumlah perempuan tiga kali lipat dibanding laki-laki, data statistik Indonesia 2000 yang diterbitkan BPS, kita mendapatkan perkiraan rasio jenis kelamin penduduk, yang dinyatakan dengan banyaknya penduduk laki-laki untuk 100 penduduk perempuan. Kita mendapati perkiraan bahwa untuk 100 perempuan ada 100,9 laki-laki di Sumatera, 99,3 laki-laki di Jawa, 100,7 laki-laki di Bali, 98,1 laki-laki di Sulawesi, 104,1 laki-laki di Kalimantan, 105,4 laki-laki di Maluku dan Papua. Untuk tingkat nasional perhitungannya adalah untuk 100 perempuan ada 99,8 laki-laki di Indonesia. ${ }^{7}$

7 Baca Kristi Purwandari, "Illusi Poligami", Jurnal Perempuan, Vol. 31, (Jakarta: Yayasan Jurnal Perempuan, 2000), h. 20. 
Jika demikian bukankah dengan poligami hanya akan menambah satu masalah baru bagi sebagian laki-laki, karena kenyatannya jumlah lelaki dan perempuan relatif seimbang, poligami dapat menggoncang keseimbangan, yaitu banyak perempuan akan menjadi istri dari sedikit lelaki. Bagaimana dengan lelaki yang tidak "kebagian"? Bukankah poligami akan menciptakan masalah baru, mulai dari frustasi seksual banyak lelaki, yang kemudian dapat mengejawantah dalam berbagai masalah sosial baru? misalnya saja kekerasan seksual, dikotomi dan kesenjangan kelas yang teramat lebar khususnya bagi kelompok lelaki, atau frustasi dari kelompok lelaki yang tersingkir dalam pertarungan memperebutkan perempuan, yang tentu berdampak pada persoalan-persoalan lain yang lebih luas.

Jika argumentasinya adalah dorongan seksual laki-laki tidak bisa dikendalikan hanya dengan satu perempuan maka pertanyaannya adalah apakah memang seksualitas lelaki sama dengan seksualitas binatang jantan? Apakah memang naluri manusia lelaki bersifat tertutup seperti hewan jantan? Bukankah naluri manusia bersifat terbuka? Bila kenyataannya sebagian lelaki memang punya kebutuhan seksual lebih besar daripada perempuan, apakah kaum lelaki puas dan bangga dapat mereduksi dirinya menjadi sekedar makhluk biologis-seksual dan menegasikan potensi-potensi kemanusianya yang jauh melampauhi aspek seksualnya?

Jika argumentasi diatas dapat dipatahkan bagaimana dengan argumentasi yang menggunakan dalil-dalil agama? tidak muda bagi masyarakat awam untuk melakukan perlawanan argumentasi karena masalah agama adalah masalah yang rawan untuk diperdebatkan.

Yang jelas bagi perempuan, hidup didunia laksana mengembara di belantara yang mengerikan di tengah buasnya monopoli patriarkhi atas segala sendi kehidupan. Ideologi patriarkhi muncul dalam bentuk simbolsimbol budaya yang memposisikan perempuan sebagai sub-ordinat dalam hubungannya dengan laki-laki diranah apapun, tidak hanya dalam keluarga tetapi juga dalam masyarakat.

Meskipun poligami telah diyakini sebagai sebagai kekerasan terhadap perempuan, tetapi sangat sulit bagi perempuan untuk menolak poligami. Hal ini terjadi karena kekuasaan patriarkhi terus menerus disokong oleh 
sistem simbol yang membutakan perempuan dan laki-laki akan suatu tatanan hubungan laki-laki dan perempuan yang lebih demokratis. Jaques Lacan, seorang filsuf Perancis mengatakan bahwa setiap masyarakat diatur lewat suatu rangkaian tanda (simbol) yang saling berhubungan, serta peranan-peranan dan ritual-ritual yang ada di masyarakat atau yang disebut dengan "aturan simbolis."

Aturan ini terus menerus memproduksi aturan main dalam masyarakat, termasuk hubungan laki-laki dan perempuan. ${ }^{8}$ Aturan simbolis yang mengatur sistem masyarakat, lahir dari poses bekerjanya tatanan kemasyarakatan (social order) sebagai norma yang mengatur tata cara warganya berhubungan satu dengan yang lain dalam aspek kehidupan sosial, politik, ekonomi dan budaya. Adalah suatu kenyataan bahwa pada masyarakat Indonesia terdapat norma-norma yang sensitivitasnya rendah terhadap kepentingan perempuan dalam kasus poligami yakni norma agama, hukum dan tradisi (adat) yang berlaku dimasyarakat.

Pada kelompok tertentu dapat ditemukan bahwa perilaku poligami menjadi suatu sistem perkawinan yang "resmi", misalnya suku-suku masyarakat adat di Irian Jaya. Selain itu dalam masyarakat juga berkembang mitos-mitos seksualitas yang turut mendukung poligami. Misalnya ada kepercayaan nafsu seksual laki-laki lebih besar dari perempuan, sementara perempuan lebih cepat tua ketimbang laki-laki. Hal ini menjadi legitimasi bagi laki-laki untuk mengawini perempuan lebih dari satu. Semua hal diatas menjadi aturan yang membuat perempuan menyetujui poligami.

\section{Norma Agama: Ketidakadilan Suami berarti Kekerasan terhadap Perempuan}

Argumentasi agama yang biasa digunakan oleh mereka yang pro poligami adalah surat al-Nisa' ayat 3 dan diambil hanya sepenggal yaitu boleh menikahi perempuan 2, 3, 4 asal bisa berbuat adil. Padahal ayat

8 Nur Imam Subono, "Negara dan Kekerasan terhadap Perempuan", Jurnal Perempuan, (Jakarta: Yayasan Jurnal Perempuan, 2000), h. 108. 
tersebut tidak dapat dipahami secara parsial dengan hanya merujuk pada bagian tertentu dari suatu ayat dan mengabaikan bagian ayat yang lain. Bahwa ayat al-Qur'an harus dilihat secara utuh atau tidak dengan sepenggal-penggal.

Menurut Syahrur, ayat tersebut memiliki jenis kalimat yang ma'thufah (berantai) dari ayat sebelumnya yaitu karena menggunakan kata "wa in...." kata ini merupakan kalimat bersyarat dalam konteks hak tehadap anak yatim yang terkait dengan surat al-Nisa' ayat 2 . sedangkan bila dilihat dari sudut pandang hudud, maka ayat tersebut memiliki kaitan yang erat antara dimensi kemanusiaan dan dimensi sosial. Selain itu ayat tersebut memiliki dua macam al-hadd yaitu al-hadd al-kamm (secara kuantitas) dan hadd fi al-kauf(secara kualitas). ${ }^{9}$

Secara kuantitas ayat ini menjelaskan bahwa jumlah minimum istri yang diperbolehkan adalah satu dan jumlah maksimal adalah empat. Dan bila ada seseorang yang beristri lebih dari itu dia telah menyalahi hudud Allah. Pemahaman seperti ini menurut Syahrur disepakati tanpa melihat konteks dan kondisi bagaimana ayat tersebut memberikan batasan (hadd fi al-kayff. ${ }^{10}$

Menurut Syahrur secara kualitas, sirri yang dimaksud di sini adalah perawan (bikr) atau janda (armalah). Bila dilihat dari ayat tersebut jelas menggunakan shigah syarth yaitu dengan kata lain bagi istri pertama tidak disyaratkan apakah dia perawan atau janda tetapi untuk istri selanjutnya disyaratkan janda yang mempunyai anak yatim. ${ }^{11}$

Sedangkan makna keadilan menurut Quraish Shihab merupakan kata jadian dari adil yang diambil dari 'adl dalam bahasa Arab. Kamuskamus dalam bahasa Arab menginformasikan bahwa kata ini pada mulanya berarti sama dimana persamaan ini dikaitkan dengan hal-hal yang bersifat imaterial. ${ }^{12}$

${ }^{9}$ Syahrur, Muhammad, 1992, al-Kitab wa al-Qur'an, Qira'ah Mu'asyarah, Kairo: Sina Publisher h. 598

${ }^{10}$ Ibid., h. 599.

${ }^{11}$ Ibid., h. 560.

${ }^{12}$ Lihat Quraish Shihab, Wawasan al-Qur'an, Bandung: Mizan (1996, h. 111) 
Menurut Abduh, apabila seorang laki-laki mampu memberikan hakhak istrinya, rusaklah struktur rumah tangga dan kacaulah penghidupan keluarga. Padahal tiang utama dalam mengatur kehidupan rumah tangga adalah adanya kesatuan dan saling menyanyangi antar anggota keluarga. Ini menunjukkan bahwa Abduh sangat menekankan keadilan kualitatif yang hakiki, seperti perasaan sayang dan kasih, yang semuanya tidak dapat diukur dengan angka-angka. Hal ini sesuai dengan makna yang dikandung dalam istilah yang digunakan oleh al-Qur'an yaitu 'adalah, yang memang memiliki makna yang lebih kualitatif. ${ }^{13}$

Adapun keadilan yang kemukakan oleh para ahli figh hingga saat ini cenderung bersifat kuantitatif yang sebenarnya lebih tepat untuk kata qisthun. Padahal keadilan kuantitatif tersebut tampak dalam aturan-aturan fiqh tentang poligami, misalnya pembagian rezeki secara merata diantara istri-istri yang dikawini, pembagian jatah hari (giliran) dan sebagainya. Para ahli fiqh tidak memperhatikan aspek-aspek kualitatif yang justru sangat menentukan. Misalnya rasa cinta, tidak pilih kasih, tidak memihak dan sebagainya. Keadilan kualitatif inilah yang seharusnya menjadi prioritas utama. Orang yang mencapai keadilan kuantitaif belum tentu mampu adil secara kualitatif.

Dalam banyak kasus poligami, keadilan kuantitatif saja seringkali terabaikan apalagi keadilan kualitatif. Suami yang mempunyai banyak istri akan mempunyai kewajiban memenuhi kebutuhan ekonomi istriistrinya, hal ini mengakibatkan banyak perempuan baik istri pertama, kedua, dan seterusnya tidak mendapatkan haknya sebagai istri. Seperti yang dialami oleh beberapa perempuan yang menjalani perkawinan poligami berikut ini:

"Saya rela bertransmigrasi ke Kalimantan agar keadaan ekonomi kami menjadi lebih baik, di sana saya juga mencari uang dengan bisnis membuka toko, tapi setelah ekonomi sudah membaik, suami

${ }^{13}$ Lihat Ahmad al-Jarjawi, Hikmah al-Tasri' wa Falsafatuhu, (Beirut: Dar al- Fikr, t.th.), hlm 18-20 sebagaimana dikutip oleh Nazaruddin Umar, "Agama dan Kekerasan terhadap Perempuan", Jurnal Dinamika HAM, Vo. 2 No. 1, April 2001, h. 29. 
berselingkuh dengan perempuan lain, akhirnya saya minta dia dipindah ke Sumedang agar dia bisa melupakan perempuan tersebut, tapi ternyata dia tidak berubah, 3 bulan di sini dia sudah punya selingkuhan lagi, yang lebih menyakitkan perempuan tersebut sering dibawah pulang ke rumah, akhirnya saya tidak kuat tinggal bersamanya, saya akhirnya pergi dari rumah tersebut dengan membawa anakanak. Sejak meninggalkan rumah tersebut sampai sekarang (dari tahun 1999- Januari 2007) tidak sepeser pun dia memberi nafka kepada saya, padahal anak-anak butuh biaya sekolah. (Ny. Aas, Cirebon) $)^{14}$

Ibu saya istri keempat, kakek saya menginginkan ibu dinikahi oleh bapak saya, menurut ibu, bapak saya sangat disegani oleh banyak orang, sering bepergian keluar negeri dan jadwal acaranya sangat padat. Saya kurang faham dengan bapak saya karena sejak usia satu tahun bapak hampir tidak pernah datang lagi sampai beliau meninggal dengan usia saya yang sudah 26 tahun. Selama itu praktis ibu yang pontang-panting membiayai kami. Bapak mewariskan banyak harta dan yayasan tapi sekarang jadi rebutan diantara semua anak dari masing-masing istri, mereka saling mengancam dan bahkan saling memperkarakan sampai ke meja hijau. Saya dari dulu tidak pernah mendapatkan apapun, dan mungkin mereka menganggap kami tidak pernah ada, cuma saya sangat sedih mengapa saya tidak punya keluarga yang utuh, saya sangat kasihan pada ibu saya, hidupnya sangat menderita... (Ny. Ami, Bandung)

Dari 2 kasus di atas menunjukkan bahwa sesungguhnya adil dalam poligami hampir tidak mungkin dapat dilakukan oleh seorang laki-laki. Dari segi materi saja sangat sulit dilakukan, apalagi dari sisi kualitas perhatian seperti kasih sayang dan cinta. Hak perempuan untuk mendapatkan kehidupan yang aman dan menjadikan keluarga yang sakinah mawaddah warahmah sesuai dengan tujuan perkawinan tidak tercapai. Padahal dalam aturan perkawinan jelas bahwa terdapat larangan bagi suami untuk tidak menyia-nyiakan istri, bahkan untuk tidak menyia-nyiakan mantan istri dalam aturan lainnya yang dipertegas dalam al-Qur'an.

\footnotetext{
${ }^{14}$ Kutipan ini diambil pada tanggal 9 Januari 2007 pada salah satu subjek sebagai istri pertama dalam perkawinan poligami.
} 
Perilaku menyia-nyiakan istri sangat mungkin dialami perempuan yang suaminya melakukan poligami ${ }^{15}$. Seperti dalam firman Allah SWT dalam al-Qur'an berikut:

"dan sekali-kali kamu tidak akan dapat berlaku adil diantara istri-istri $(\mathrm{mu})$, walaupun kamu sangat ingin berbuat demikian, karena itu janganlah kamu terlalu cenderung (kepada yang kamu cintai), sehingga kamu biarkan yang lain terkatung-katung..." (QS. al-Nisa [4]: 129)

Selain itu diperkuat dalam hadits yang disampaikan Nabi Muhammad SAW yang secara keras mengandung ancaman bagi suami yang tidak berlaku adil, dalam sabdanya berikut ini yang artinya:

Dari Abu Hurairah, Nabi SAW bersabda: "Barang siapa yang mempunyai dua istri, lalu berat sebelah keada salah satunya, maka dia akan datang pada hari kiamat dengan salah satu bahunya miring." (Hadits riwayat: Ahmad, Abu Dawud, Nasa'i dan Ibnu Majah)

Sebagaimana terlihat dalam kasus diatas, ketidakadilan yang tidak dipenuhi oleh laki-laki, menjadikan perempuan sebagai istri sebagai korban, anak-anak merekapun berduka mendapatkan keluarga yang tidak sempurna. Kasih sayang tidak sepenuhnya mereka dapatkan, belum lagi pengabaian ekonomi dan pendidikan yang terkatung-katung. Perlu dipahami bahwa pengabaian dari semua kebutuhan tersebut merupakan bagian dari kekerasan terhadap perempuan dalam rumah tangga.

\section{Fakta Poligami sebagai Kekerasan terhadap Perempuan}

Menurut LBH APIK, poligami merupakan bentuk penampakan konstruksi kuasa laki-laki yang superior dengan nafsu menguasai perempuan, disisi lain faktor biologisseksual juga mempengaruhi bahkan demi prestise tertentu. Namun yang nampak dari kesemuanya itu adalah poligami telah menambah beban kesengsaraan perempuan terhadap sekian banyak beban

${ }^{15}$ Lihat Fayumi, Badriyah, "Islam dan Masalah Kekerasan terhadap Perempuan" dalam Arini, Amiruddin dan Abdul Qadir, Faqihuddin (ed.), Tubuh, Agama dan Kedaulatan Perempuan: Bunga Rampai Pemikiran Ulama Muda, (Jakarta: Rahima, The Ford Foundation dan LKIS, 2002). 
yang sudah ada, dan jika itu kenyataannya maka poligami adalah konsep penindasan terhadap perempuan yang tidak berpihak pada rasa kemanusiaan dan keadilan. ${ }^{16}$

Poligami merupakan bentuk subordinas dan diskriminasi terhadap perempuan, dimana didasarkan pada keunggulan atau superioritas jenis kelamin tertentu atas jenis kelamin lainya. Pengakuan yang absah terhadap hirarki jenis kelamin dan pengutamaan privilis seksual mereka atas yang lainnya. Ketentuan ini sangat bertentangan dengan prinsip-prinsip persamaan, anti diskriminasi serta anti kekerasan yang dianut dalam berbagai instrument hukum yang ada. (UUD 1945, UU HAM, UU No. 1/84, GBHN 1999, Deklarasi Penghapusan Kekerasan terhadap Perempuan). 17

Adanya fakta bahwa sejumlah perempuan menerima poligami tidak menghilangkan hakekat diskriminasi seksual dalam institusi poligami tersebut. Dan penerimaan mereka terhadap poligami adalah bentuk internalized oppression yang mana sepanjang hidupnya perempuan telah disosialisasikan pada sistem nilai yang diskriminasi seksual dalam institusi poligami tersebut. ${ }^{18}$

Dalam beberapa kasus yang saya jumpai, banyak perempuan yang merasa hancur dan dicabik-cabik harga dirinya karena poligami.

"Saya tidak mengerti dengan perilaku suami saya, sebelum berangkat kerja saya menyiapkan semua keperluan dia dan keempat anak kami. Mulai dari air hangat, baju yang siap pakai serta sarapan. Setiap dia pulang saya selalu membukakan baju, sepatu sampai kaos kaki, menyiapkan air hangat, makan siang dan setiap usai $\mathrm{ML}$ saya yang membersihkan seluruh badan dia dengan air hangat, dengan dia menikah lagi rasanya diri saya hancur, rasanya semua yang saya lakukan tidak berarti apa-apa lagi." (Ny. Titik) ${ }^{19}$

\footnotetext{
${ }^{16}$ Cuplikan Siaran Pers LBH-APIK, tanggal 24 Juli 2003. h. 118.

${ }^{17}$ Ibid., h. 119

18 Ibid.

${ }^{19}$ Kutipan ini diambil pada tanggal 28 Februari 2011 pada salah satu subjek sebagai istri pertama dalam perkawinan poligami
} 
Poligami tidak hanya berdampak pada hilangnya kepercayaan diri perempuan sebagai istri tapi juga pada kondisi psikologis anak.

"Saya tidak tahu apa yang harus saya lakukan lagi, saya hanya bisa menangis dan menahan semuanya sendirian, sesak dada saya dengan semua ini, kadang kalau tidak ingat anak-anak rasanya saya mau bunuh diri saja, saya tidak sanggup dengan kondisi ini. saya malu bertemu dengan banyak orang, rasanya semua menunjukkan jarinya ke saya bahwa saya adalah istri yang tidak bisa menservice suami, selama ini saya sudah memberikan yang terbaik padanya, apapun sudah saya lakukan untuknya. Saya tidak bisa bayangkan betapa hati anak-anak saya terkoyak, mereka yang biasanya ceria dan bangga dengan bapaknya, sekarang jadi murung dan marah-marah, sering tidak pulang, bahkan anak-anak saya sudah mulai mengkonsumsi narkoba, saya tidak sanggup dengan semuanya, apa salah saya sehingga suami saya tega melakukan semuanya pada saya dan anakanak?" (Ny. Joy, Bandung) ${ }^{20}$

Meskipun suaminya telah kembali ke istri pertamanya, namun perkawinan poligami telah menyisakan derita yang berkepanjangan.

"Semua teman-teman saya menyarankan untuk menggugat cerai suami saya, saya dianggap bodoh oleh teman-teman. Mungkin saya memang bodoh tapi saya tidak bisa berbuat apa-apa atas semua yang diperbuat oleh suami saya, bayangin mbak dia menikah tanpa sepengetahuan saya, dan hampir tidak pernah pulang, 2 tahun kemudian mereka bercerai, madu saya pergi jadi TKI di Arab Saudi, anaknya yang berusia 1 tahun saya yang mengasuh. Suami saya meminta maaf pada saya karena menelantarkan saya dan anak-anak, tapi enam bulan kemudian suami saya sudah jarang pulang lagi, ternyata dia menikah dengan mahasiswanya yang sudah punya satu anak, sekarang setelah satu tahun hidup dengan perempuan tersebut, katanya dia ingin go out. Sekarang jadi sering dirumah tapi tidak jaminan kalau dia tidak mengulanginya lagi, hubungan kami (saya, suami dan anak-anak) sudah tidak seperti dulu, anak-anak sudah

\footnotetext{
${ }^{20}$ Kutipan ini diambil pada tanggal 26 Februari 2011 pada salah satu subjek sebagai istri pertama dalam perkawinan poligami.
} 
malas berkomunikasi dengan bapaknya. saya bertahan hanya demi anak-anak meski saya sangat tersiksa.

Para pria pelaku poligami sering tidak memenuhi kewajibannya menafkahi istri dan anak secara mencukupi. Cukup banyak perempuan yang hidup dalam perkawinan poligami harus memenuhi kebutuhan ekonomi keluarganya sendiri. Bahkan tidak jarang suami justru tidak betanggung jawab, malah ada suami yang 'numpang hidup' pada istrinya, dengan kerelaan istri ataupun dengan cara kekerasan.

"Boro-boro ngasih jatah finansial, setiap ke sini juga aku yang ngongkos. Uangku sudah banyak yang aku berikan, kadang katanya buat modal atau untuk membiayai sekolah anak-anaknya dari istri pertama." (Ny. Eti, Bandung)

Poligami menurut Lies Markus merupakan proses dehumanisasi perempuan, mengambil pandangan ahli pendidikan Freire, dehumanisasi dalam konteks poligami terlihat manakalah perempuan yang dipoligami mengalami self depreciation. Mereka membenarkan bahkan bersetuju dengan tindakan poligami meskipun mengalami penderitaan yang luar biasa dan tidak sedikit diantara mereka yang menganggap bahwa penderitaan itu adalah pengorbanan yang sudah sepatutnya dijalani. Dalam konteks Poligami, pembunuhan karakter terjadi ketika praktik poligami telah membinasakan kemanusiaan korban. Mereka benar-benar dibuat kehilangan daya, kehilangan harga diri, kehilangan logika, dan mengalami dehumanisasi. $^{23}$

Dalam kasus poligami terjadi kekerasan yang beruntun baik terhadap istri pertama maupun istri kedua. Dimana istri pertama tidak hanya mengalami pengingkaran komitmen perkawinan tetapi juga terjadi tekanan psikologis, ekonomi, seksual hingga fisik. Belum lagi dipandang ibah bahkan sikap sinis masyarakat yang makin merendahkan.

\footnotetext{
${ }^{21}$ Kutipan ini diambil pada tanggal 27 Februari 2011 pada salah satu subjek sebagai istri pertama dalam perkawinan poligami.

${ }^{22}$ Kutipan ini diambil pada tanggal 1 Januari 2011 pada salah satu subjek sebagai istri kedua dalam perkawinan poligami.

${ }^{23}$ Baca Memilih Monogami: Pembacaan atas al-Qur'an dan Hadits Nabi, (Yogyakarta Pustaka Pesantren: 2005), h. 39-47.
} 
Sementara bagi istri kedua, hal yang tidak jauh berbeda juga terjadi. Selama ini ada pandangan bahwa istri kedua mendapatkan keuntungan dari poligami. Misalnya istri kedua selalu mendapatkan keuntungan tidak saja dari segi psikologis (lebih disayang suami) tapi juga dari segi ekonomis. Hal ini mungkin sesuai dengan pameo yang beredar di masyarakat bahwa "istri muda lebih disayang ketimbang istri tua." Walaupun demikian istri kedua tetap dihantui kekerasan dari sang suami. Keadaan seperti ini berlaku bagi semua perempuan tanpa memandang tinggi rendahnya status sosial perempuan.

Sama dengan istri pertama, maka istri kedua pun tidak luput dari cibiran masyarakat. Seringkali istri muda mendapat label sebagai perempuan "pelanggar kehormatan", "perempuan penggoda" dan yang lebih menyedihkan lagi mereka juga dicap sebagai "perempuan binal alias gatal." Namun satu hal yang seringkali dilupakan adalah pelanggaran yang dilakukan oleh laki-laki. Dalam hal ini masyarakat kadang bungkam, dan take for granted. Seorang laki-laki yang beristri banyak tidak mendapat sangsi moral dan sosial yang pantas. Bahkan hal itu seakan telah menjadi jaminan untuk membuktikan kekuasaan dan kejantanan laki-laki. Sebagai contoh, beberapa tokoh masyarakat bangga mengaku bahwa mereka beristri banyak.

Fakta diseputar poligami menunjukkan bahwa praktek poligami lebih banyak merugikan masyarakat, banyak penderitaan yang timbul akibat poligami. Penderitaan tersebut dialami baik istri pertama juga istri yang lainnya serta anak-anak. Berdasarkan data dari 106 kasus poligami yang didampingi oleh LBH APIK Jakarta tahun 2001-2005, poligami memperlihatkan bentuk-bentuk kekerasan terhadap istri-istri dan anakanak mereka, mulai dari tekanan psikis, penganiayaan fisik, penelantaran istri dan anak-anak, ancaman dan teror serta pengabaian hak seksual istri ${ }^{24}$ sebagaimana dapat dilihat dalam tabel 1.

\footnotetext{
${ }^{24}$ www.lbhapik.or.id
} 
Tabel 1.

Dampak Poligami terhadap Istri Pertama

\begin{tabular}{|c|l|c|}
\hline No & \multicolumn{1}{|c|}{ Jenis Dampak } & Jumlah Variasi Dampak \\
\hline 1 & Tidak diberi nafkah & 37 \\
\hline 2 & Tekanan psikis & 21 \\
\hline 3 & Penganiayaan fisik & 7 \\
\hline 4 & Diceraikan oleh suaminya & 6 \\
\hline 5 & Diterlantarkan/ ditinggalkan suami & 23 \\
\hline 6 & Pisah ranjang & 11 \\
\hline 7 & Mendapat teror dari istri kedua & 2 \\
\hline & Jumlah & 107 \\
\hline
\end{tabular}

Catatan: ada istri yang menerima dampak lebih dari satu.

(Sumber: LBH APIK Jakarta, 2005)

Menurut penemuan Rifka Annisa $\mathrm{WCC}^{25}$, perempuan yang hidup berumah tangga sangat rentan tehadap tindak kekerasan dari pasangan hidup yang memiliki affair dengan perempuan lain. ${ }^{26}$ Dan hal itu tentu juga terjadi pada perkawinan yang tidak resmi. Sebagaimana terlihat dalam tabel 2 dan tabel 3 tentang status korban kekerasan.

Tabel 2.

Presentase Kekerasan terhadap Perempuan dari Pasangan Hidup yang Memiliki Affair dengan Perempuan lain

\begin{tabular}{|c|l|c|}
\hline NO & Jenis Kekerasan & Presentase \\
\hline 1 & Kekerasan emosional & 46,1 \\
\hline
\end{tabular}

${ }^{25}$ Lembaga yang concern pada pendampingan perempuan korban kekerasan, bertempat di Yogyakarta.

${ }^{26}$ Litbang Rifka Annisa WCC, Laporan Data Kasus Tahun 2001, (Yogyakarta: Rifka Annisa, 2001), h. 5 dan 8. Fakta jumlah perkawinan poligami secara formal sulit ditemukan. Data dari Rifka Annisa hanya memberi sedikit gambaran kerawanan perkawinan poligami bagi perempuan. Hal ini ditengarai karena berbagai pihak lebih suka menutupi perkawinan poligaminya. Proses legalisasi untuk perkawinan kedua juga lebih sulit dilakukan, maka tidak heran serig juga ditemui penggelapan terhadap status perkawinan laki-laki untuk melegalkan perkawinan atau dilakukan di bawah tangan. Hal ini membuat catatan tentang perkawinan poligami sulit ditemukan. 


\begin{tabular}{|c|l|c|}
\hline 2 & Kekerasan fisik & 29,4 \\
\hline 3 & Kekerasan ekonomi & 5,6 \\
\hline 4 & Kekerasan seksual & 18,9 \\
\hline
\end{tabular}

Sumber: Rifka Annisa WCC, 2001

Tabel 3.

Status Korban yang Mengalami Kekerasan

\begin{tabular}{|c|l|c|}
\hline No. & \multicolumn{1}{|c|}{ Status Korban } & Jumlah \\
\hline 1. & Dipoligami resmi & 2,5 \\
\hline 2. & Poligami sirri & 5,1 \\
\hline 3. & Korban selingkuh & 36,3 \\
\hline 4. & Ditinggal pergi suami & 2,5 \\
\hline 5 & Dicerai & 4,2 \\
\hline 6. & Istri kedua & 0,4 \\
\hline 7. & Dijadikan wil-wanita idaman lain & 0,4 \\
\hline
\end{tabular}

Sumber: Rifka Annisa WCC, 2001

Dampak poligami pada tabel diatas merupakan bentuk kekerasan terhadap perempuan, bahkan dapat diartikan penindasan yang merugikan perempuan. Tidaklah mengherankan apabila sejumlah Negara Islam seperti Turki, Tunisia dan Siria melarang dilakukannya praktek poligami ini. Mengutip Habib Ruqoyba, mantan Presiden Tunisia, bahwa "keluarga adalah tonggak masyarakat dan keluarga dapat berhasil dengan baik dengan dasar saling menghormati dan menghargai antar pasangan. Salah satu bentuk saling menghargai dan menghormati adalah dengan melaksanakan pernikahan monogami.

Disini beliau menyadari bahwa keluarga memiliki peran penting sebagai tonggak masyarakat. Dengan menerapkan kebijakan larangan poligami beliau berusaha menyelamatkan masa depan anak-anak dan membiarkan mereka tumbuh dengan rasa aman, percaya diri serta tanpa konflik keluarga yang menimbulkan trauma. 


\section{E. Introspeksi terhadap Dukungan Poligami}

Poligami telah ada dan dipraktikan jauh sebelum Islam datang. Bukan Islam yang membawa poligami. Sebaliknya, Islam melalui AlQur'an dan Hadits yang mengkritik poligami. Kritik inilah yang harus diteruskan terhadap praktik-praktik poligami yang marak akhir-akhir ini. ${ }^{27}$

Marilah kita berfikir sejenak dan mengintrospeksi diri, apakah kita benar-benar menghormati dan menghargai perempuan ketika kita mempraktekkan poligami atau ketika membenarkan praktek-praktek poligami yang marak terjadi dalam masyarakat kita sekarang. ${ }^{28}$

Kita perlu mempertanyakan apakah mereka yang berpoligami melakukannya karena kepentingan sosial seperti yang didakwakan oleh rasul, untuk mengimbangi kepentingan jumlah perempuan yang lebih banyak dari laki-laki, untuk membantu dan mengentaskan perempuan dari keterpurukan, untuk menyelesaikan persoalan peperangan dan membantu para janda dan anak yatim? ataukah sebenarnya mereka berpoligami untuk kepentingan dirinya dengan berlindung pada kepentingan-kepentigan sosial, untuk menaikkan prestise sosialnya sebagai pria macho yang sanggup menaklukan banyak perempuan, untuk memanfaatkan tubuh perempuan sebagai pemuas nafsunya atau memanfaatkan tenaganya dengan bayaran murah atau sekedar memuaskan keinginanya untuk menjelajah pengalaman dengan banyak perempuan? ${ }^{29}$

Bila poligami dilakukan dengan memilih mengawini perempuanperempuan muda atau menarik, alasannya tempaknya jelas. Alasannya bukan ingin berbuat baik atau menolong orang lain. Yang berbicara sesunguhnya adalah hasrat seksual dan egosentrisme, alias keberpusatan pada diri sendiri. Tetapi hasrat seksual dan egosentrisme tersebut kemudian diselubungi atau dipayungi alasan-alasan lain termasuk alasan keagamaan yang membuat pihak lain takut dan bungkam.

${ }^{27}$ Baca Memilih Monogami..., h. 9.

${ }^{28}$ Ibid., h. 11.

${ }^{29} \mathrm{Ibid}$. 
Jika demikian adanya maka sesungguhnya mereka tidak menghormati perempuan sebagaimana dia memandang dirinya sendiri. Jika memang demikian sebaiknya poligami tidak menggunakan dalil-dalil agama. Sebab misi agama jauh lebih mulia ketimbang sekedar membenarkan pemuasan nafsu biologis yang berakibat derita lahir batin perempuan.

\section{F. Kesimpulan}

Poligami merupakan suatu jalan yang diambil perempuan karena keterpaksaan. Poligami menjadi suatu dilema, diterima ataupun tidak tetap memiliki konsekuensi terjadinya kekerasan terhadap perempuan. Istri pertama maupun kedua, sama sama terjerat dan tertindas dalam sistem kemasyarakatan yang dikuasai oleh sistem masyarakat patriarkhi. Berangkat dari analisa tersebut, maka segala argumen yang menyatakan bahwa poligami telah menyelamatkan perempuan tidak benar sama sekali.

Praktek perkawinan poligami lebih berdampak kemadharatan daripada kemaslahatan. Dalam perkawinan poligami banyak terjadi pengabaian hak-hak kemanusiaan yang semestinya didapatkan oelh seorang istri dan anak dalam keluarga. Hal ini yang kemudian sering muncul adalah adanya permusuhan diantara keluarga para istri dalam perkawinan poligami. Realitasnya banyak kasus poligami yang memicu bentuk-bentuk kekerasan dalam rumah tangga (KDRT) lainnya, meliputi kekerasan fisik, psikis, seksual dan ekonomi dan sebagainya yang dialami oleh perempuan dan anak-anak menjadi bukti bahwa semestinya ada peninjauan dan pertimbangan kembali tentang adanya praktek perkawinan poligami. ${ }^{30}$

Bila mengacu pada kaidah fiqh, telah dikatakan bahwa "menolak kemafsadatan lebih didahulukan dari meraih kemaslahatan" artinya bahwa apabila sama antara kemafsadatan dan kemaslahatan maka hal itu harus ditangguhkan dan jangan dilaksanakan. Artinya bahwa menolak kemafsadatan lebih didahulukan daripada meraih kemaslahatan yang 2002 h. 77.

${ }^{30}$ Lihat tulisan Khoiruddin Nasution dalam Jurnal Musawwa Vol. 1 No. 1, Maret 
sedikit. Berdasarkan kaidah tersebut nampak bahwa apabila perkawinan poligami banyak memberikan mafsadat daripada maslahatnya sudah saatnya perkawinan seperti itu ditangguhkan dan jangan dilaksanakan. Bahwa perkawinan dengan menggunakan asas monogami yang dilandasi cinta dan kasih sayang untuk mencapai mawadah wa rahmah merupakan konsep perkawinan yang semestinya menjadi satu model yang ditetapkan.[]

\section{Daftar Pustaka}

A. Qodir, Memilih Monogami: Pembacaan atas al-Qur'an dan Hadits Nabi, Yogyakarta: Pustaka Pesantren, 2005.

Badan Pusat Statistic, Statistic Indonesia, Statistically Year Book of Indonesia 2000, Jakarta: Badan Pusat Statistic, 2000.

Chodorow, Nancy J., Feminism and Psychoanalytic. New Haven: Yale University Press, 1989.

Pusat Pembinaan Bahasa Indonesia, Kamus Besar Bahasa Indonesia, Jakarta: Balai Pustaka, 1990.

Musda Mulia, Pandangan Islam tentang Poligami, Jakarta: LKAJ, SP dan Ford Foundation, 1999.

Mansour Fakih, Analisis Gender dan Transformasi Sosial, Yogyakarta: Pustaka Pelajar, 1996.

Hutchison, Michael, The Anatomy of Sex and Power, An Investigation of Mind-Body Politics, New York: William Morrow and Company, Inc, 1990.

Millet, Kate, Sexual Politics, New York: Doubleday \& Co., Inc, 1970.

Syahrur, Muhammad, al-Kitab wa al-Qur'an, Qira'ah Mu'asyarah, Kairoh: Sina Publisher, 1992.

Jumal Perempuan, No. 22, Maret 2002, Yayasan Jurnal Perempuan. , No. 31, September 2003, Yayasan Jurnal Perempuan.

Quraish Shihab, Wawasan al-Qur'an, Bandung: Mizan 1996. 